\title{
DEVELOPMENT OF EDUCATION GAME "HALO INDONESIA" BASED ON ANDROID FOR WALAILAK UNIVERSITY STUDENTS OF THAILAND
}

\author{
Wanda Ramansyah, Ariesta Kartika Sari, Pensri Panich, Nurrohmat Hidayatullah Akbar \\ (Universitas Trunojoyo Madura), (W alailak University)
}

\begin{tabular}{lll}
\hline A R T I C L E I N F O & A B S T R A C T \\
$\begin{array}{ll}\text { Keyword: } & \text { The obstacle experienced by Thai citizens to learn Indonesian is the difficulty of } \\
\text { Games, } & \text { pronouncing the letters and words in Indonesian properly and correctly. To overcome } \\
\text { Education, } & \text { these obstacles, a solution is needed in the form of developing an educational game } \\
\text { Halo Indonesia } & \text { "Halo Indonesia" for learning Indonesian for Thai citizens. This educational game will } \\
& \text { provide clear instructions on how to pronounce letters and words in Indonesian } \\
& \text { because there are sounds and writing to guide users to learn. }\end{array}$ \\
\hline
\end{tabular}

\section{INTRODUCTIONS}

Indonesian has a positive trend in its development, especially in the Asian region. In the past decade, there has been increasing interest among people from abroad, especially Thailand, to learn Indonesian. The interest of the Thai people in learning the Indonesian language is evident in the implementation of Indonesian language learning in educational institutions in Thailand in both secondary schools and universities. Indonesian in secondary schools in Thailand is used as a choice subject that students can choose from. Whereas in higher education, besides being used as an elective course in nonlanguage study programs, Indonesian is used as a study program in a department or faculty that has a concentration in the field of language. Brahma who was one of the students from Indonesia who had the opportunity to take part in the Indonesia Youth Culture Exchange program (Berita Ekspress. 2016, 22 February. Kaget Banyak Mahasiswa Thailand Fasih Berbahasa Indonesia. Diakses 4 November 2018. http://www.beritaekspres.com/2016/02/22/kaget-banyak-mahasiswa Thailand-fasih-berbahasaindonesia/) explained that Indonesian became a favorite subject to be studied compared to languages from other ASEAN member countries.

This phenomenon is followed by the seriousness of educational institutions in Thailand to organize Indonesian language learning for its citizens. Educational institutions in Thailand conduct Indonesian language learning both within their institutions and outside their institutions, even if the education institution often sends Thai students or students directly to come and live in Indonesia within a few weeks to several years to focus on learning Indonesian. Although the activity of sending Thai students or students to Indonesia requires a large fee, it does not reduce the enthusiasm of Thai citizens to come directly and learn Indonesian in Indonesia.

Of course, the great interest of Thai citizens to learn Indonesian is able to be facilitated by related parties such as the Indonesian Embassy and higher education institutions, especially the faculties or departments of the Indonesian Language in Indonesia. Many Indonesian language learning programs have been conducted by the Indonesian Embassy in Thailand to facilitate Thai citizens to learn

\footnotetext{
* Corresponding author.

E-mail addresses: wandaramansyah@trunojoyo.ac.id (Wanda Ramansyah), ariestakartika@ymail.com (Ariesta Kartika Sari), penseri.panich@gmail.com (Pensri Panich), akbar@rubicstudio.com (Nurrohmat Hidayatullah Akbar)
}

ISSN : 2597-7385 (Online) - ISLLAC : Journal of Intensive Studies on Language, Literature, Art, and Culture is licensed under Creative Commons Attribution-ShareAlike 4.0 International License (http://creativecommons.org/licenses/BY/4.0/). 
Indonesian. In addition, there have also been many private and state universities in Indonesia that provide programs or services to accept foreign students who want to learn Indonesian.

A big interest for Thais to learn Indonesian does not mean there are no obstacles. According to the Tribune News on its website http://www.tribunnews.com/ nasional/2017/10/26/bahasa-indonesiajadi-tren-di-thailand-kenapa-yah, states that Thai citizens have difficulty in pronouncing and reciting letters and Indonesian words because there are linguistic differences between Indonesian and Thai. Furthermore, Kompasiana on its website https://www.kompasiana.com/genturtama/58e6650ae7afbd720ec119d9/trenanak-muda-thailand-belajar-bahasa-indonesia, reported that Thai students have not been fluent in reading Latin letters in Indonesian because of people's habits Thailand, which uses Thai letters every day.

From these constraints and obstacles, efforts need to be made to overcome them, where one of the efforts that can be done is to create an Android-based educational game. Smaldino (2011: 39) states that games provide a competitive environment in which students will follow the prescribed rules as they try to achieve challenging educational goals. The statement indicates that the educational game can invite students to a learning atmosphere with challenging and enjoyable situations.

Educational games have been researched and developed in Indonesia because educational games are becoming the trend of today's learning media. Ariona (2014) in her journal entitled "Educational Games for Color Recognition as a Media for Android-Based Preschool Children Learning" concluded that color recognition education games as a medium for learning preschool children are validly used as learning media for preschoolers. This is because the educational game is able to foster student creativity and activity which is known from the acquisition of the results of the observation sheet analysis with an average of each indicator of creativity reaching $84.95 \%$, while the activity indicator obtained $79.24 \%$ results which are both included in the good category. While Aprilina (2014) in a journal entitled "Designing Educational Games Cooking for Child" states that educational games are able to train memory and provide entertainment for children.

From the introduction above, it is necessary to make an Android-based "Halo Indonesia" educational game for basic Indonesian language learning for Thais. The game aims to make it easier for Thai citizens to learn the basics of Indonesian, especially how to pronounce and pronounce letters and words in Indonesian correctly and correctly. The educational game that will be developed is of course made and adapted to the character of Thai citizens who are learning Indonesian.

\section{METHOD}

The method of developing an educational game "Halo Indonesia" uses the ADDIE Model described in the following chart:

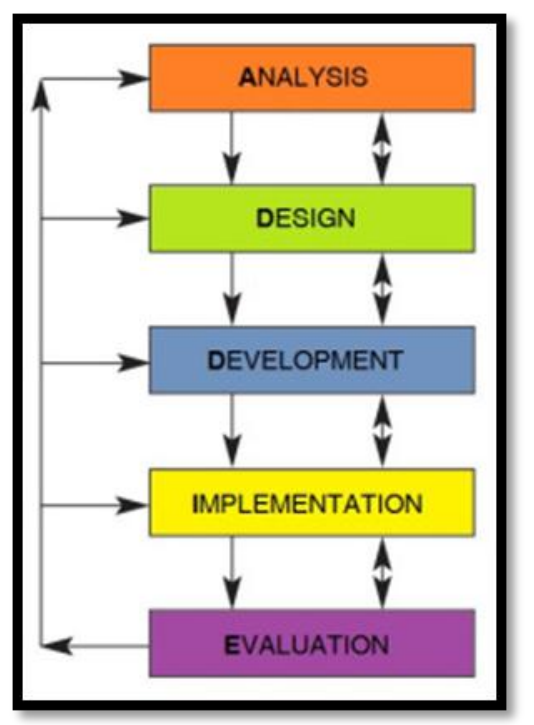

\section{Analysis}

Chart 1. ADDIE Model Development Stages (Source: Sink, 2014)

The analysis phase is directed at the activity of extracting information for needs analysis, which is an activity to survey the environment or class as a development target to determine what things are the basis, priorities, and objectives of developing a learning media product. Some things that are usually 
analyzed at this stage are subject analysis and learning objectives (competencies to be mastered by students), analysis of the characteristics of students, analysis of the learning environment, problem analysis in learning, and analysis of learning media to overcome the problems that occur. These analyzes must be carried out and obtained the right data because the analysis phase will affect the next stages. If the analysis stage is done correctly, the development will be more directed and targeted so that learning problems can be overcome.

Design

The design phase is the stage in which the developer designs alternative solutions in the form of blueprints, concepts, or design of a learning media based on the developmental objectives data obtained at the analysis stage. Blueprints must be made based on predetermined learning goals, conformity with the character of the learners, conformity with the learning environment, conformity with the problems to be addressed, and conformity with the right type of learning media. The Blueprint can be made in the form of design, sketch, scheme, flowchart, storyboard, scenario, script, draft, design drawing, and illustration that are used as the basis and clarify the direction of the development of learning media. In this design phase, it must be remembered that the blueprint that is designed must refer to the theories, concepts, and principles of learning media. This design stage must be done precisely, specifically, and clearly so that it can facilitate the developer in the next stage.

\section{Development}

The development stage is the stage where the blueprint that has been made at the design stage is then realized to be a real product of specific learning media. At this stage, the developer carries out activities to make or modify teaching materials in such a way that they are tangible learning media that are ready to be applied in a predetermined learning environment or class.

\section{Implementation}

The implementation phase is the step of implementing or actual realization of learning media that has been developed in the scope of development. Implementation in the scope of development must be applied in a real and not modest manner. In the sense that learning media must be fully and comprehensively applied within the scope of development, not just for the presentation of instructional media in passing. Must be applied in the actual learning conditions within the scope of development especially in the classroom.

\section{Evaluation}

The evaluation phase is the stage where the developer conducts an evaluation to determine the extent to which the learning media implementation refers to the predetermined development goals. At this stage, the results of evaluations will be presented from the validator (expert) and students (learning media users). The results of the evaluation of the two scopes of development will bring up quantitative and qualitative data. Quantitative data from the evaluation results will bring up data in the form of respondents' assessment in the form of numbers or percentages related to the feasibility of the learning media developed. While the qualitative data from the evaluation results will bring up data in the form of input, criticism, and suggestions related to the learning media products developed.

\section{FINDINGS AND DISCUSSION \\ Findings}

From the development that has been created, the next step is to test the feasibility of educational game products "Halo Indonesia" for several School Of Liberal Arts students, Walailak University in Thailand to determine the effectiveness, efficiency, and media appeal of the questionnaire that has been prepared. Fill out the questionnaire using five scales of product assessment, namely: (1) very poor, (2) not good, (3) good enough, (4) good, and (5) very good. After the questionnaire is collected, the percentage of each question in the questionnaire with the formula will be calculated according to Komang I. Sudarman (2006) is as follows:

$$
\text { Percentage of answers }=\frac{F}{N} \times 100 \%
$$

Information:

$\mathrm{F}=$ Frequency of subjects who choose alternative answers

$\mathrm{N}=$ Total number of subjects (total respondents) 
Giving meaning and decision making about the quality of educational game products will use conversion level attainment with a scale like a table below:

Table 1. Conversion Levels of Achievement and Qualification

\begin{tabular}{|c|c|}
\hline Achievement level & Qualification \\
\hline $90 \%-100 \%$ & Very high, no revisions needed \\
\hline $75 \%-89 \%$ & High, no need for revisions \\
\hline $65 \%-74 \%$ & High enough, it needs revision \\
\hline $55 \%-64 \%$ & Less high, need revision \\
\hline $0 \%-54 \%$ & Very low, big revisions \\
\hline
\end{tabular}

The results of this data analysis will be used to revise the product development, review the product, and provide further advice on utilization and development.

From product testing both individually ( 3 students), small groups ( 9 students), and large groups (21 students) obtained the following data:

Table 2. Components Assessed in Individual Trials

\begin{tabular}{|c|c|c|c|c|c|}
\hline No. & Components assessed & $\begin{array}{l}\text { Score of } 3 \\
\text { respondents }\end{array}$ & $\begin{array}{l}\text { Total } \\
\left(\sum\right) \\
\text { score }\end{array}$ & $\begin{array}{l}\text { Total }\left(\sum\right) \\
\text { maximum } \\
\text { score }\end{array}$ & $\begin{array}{l}\text { Percentage } \\
(\%)\end{array}$ \\
\hline 1. & $\begin{array}{l}\text { The ability of educational } \\
\text { games is able to convey the } \\
\text { subject matter of letters } \\
\text { and basic words. }\end{array}$ & 443 & 11 & 15 & $73 \%$ \\
\hline 2. & $\begin{array}{l}\text { Clarity of contents in the } \\
\text { educational game. }\end{array}$ & 453 & 12 & 15 & $80 \%$ \\
\hline 3. & $\begin{array}{l}\text { Animated clarity in } \\
\text { educational games. }\end{array}$ & 454 & 13 & 15 & $87 \%$ \\
\hline 4. & $\begin{array}{l}\text { Text and voice clarity in } \\
\text { the educational game. }\end{array}$ & 443 & 11 & 15 & $73 \%$ \\
\hline 5. & $\begin{array}{l}\text { The ability of educational } \\
\text { games to facilitate learning. }\end{array}$ & 444 & 12 & 15 & $80 \%$ \\
\hline 6. & $\begin{array}{l}\text { Ease when operating or } \\
\text { running an educational } \\
\text { game. }\end{array}$ & 343 & 10 & 15 & $67 \%$ \\
\hline 7. & $\begin{array}{l}\text { Visual appearance (picture, } \\
\text { video, or animation) in } \\
\text { facilitating learning. }\end{array}$ & 444 & 12 & 15 & $80 \%$ \\
\hline 8. & $\begin{array}{l}\text { Audio appeal (music, } \\
\text { sound effects, or narration) } \\
\text { in an educational game. }\end{array}$ & 454 & 13 & 15 & $87 \%$ \\
\hline 9. & $\begin{array}{l}\text { Display text and writing } \\
\text { (font) in educational } \\
\text { games. }\end{array}$ & 443 & 11 & 15 & $73 \%$ \\
\hline 10. & $\begin{array}{l}\text { Combination, order and } \\
\text { color selection in } \\
\text { educational games. }\end{array}$ & 444 & 12 & 15 & $80 \%$ \\
\hline \multicolumn{5}{|c|}{ Overall percentage average } & $78 \%$ \\
\hline
\end{tabular}

Table 3. Components Assessed in Small Group Trials

\begin{tabular}{|l|l|c|c|c|c|}
\hline No. & Components assessed & $\begin{array}{l}\text { A score of 9 } \\
\text { respondents }\end{array}$ & $\begin{array}{l}\text { Total } \\
\left(\sum\right) \\
\text { score }\end{array}$ & $\begin{array}{l}\text { Total }\left(\sum\right) \\
\text { maximum } \\
\text { score }\end{array}$ & $\begin{array}{l}\text { Percentage } \\
\mathbf{( \% )}\end{array}$ \\
\hline 1. & $\begin{array}{l}\text { The ability of educational } \\
\text { games is able to convey the } \\
\text { subject matter of letters }\end{array}$ & $\begin{array}{c}4544454 \\
45\end{array}$ & 39 & 45 & $87 \%$ \\
\hline
\end{tabular}

102 | ISLLAC : Journal of Intensive Studies on Language, Literature, Art, and Culture 


\begin{tabular}{|c|c|c|c|c|c|}
\hline & and basic words & & & & \\
\hline 2. & $\begin{array}{l}\text { Clarity of contents in the } \\
\text { educational game. }\end{array}$ & $\begin{array}{c}5445333 \\
54\end{array}$ & 36 & 45 & $79 \%$ \\
\hline 3. & $\begin{array}{l}\text { Animated clarity in } \\
\text { educational games. }\end{array}$ & $\begin{array}{c}5545444 \\
54\end{array}$ & 41 & 45 & $90 \%$ \\
\hline 4. & $\begin{array}{l}\text { Text and voice clarity in } \\
\text { the educational game. }\end{array}$ & $\begin{array}{c}5544334 \\
43 \\
\end{array}$ & 35 & 45 & $77 \%$ \\
\hline 5. & $\begin{array}{l}\text { The ability of educational } \\
\text { games to facilitate learning. }\end{array}$ & $\begin{array}{c}4444444 \\
43\end{array}$ & 35 & 45 & $78 \%$ \\
\hline 6. & $\begin{array}{l}\text { Ease when operating or } \\
\text { running an educational } \\
\text { game. }\end{array}$ & $\begin{array}{c}4434333 \\
44\end{array}$ & 33 & 45 & $73 \%$ \\
\hline 7. & $\begin{array}{l}\text { Visual appearance (picture, } \\
\text { video, or animation) in } \\
\text { facilitating learning }\end{array}$ & $\begin{array}{c}5544444 \\
44\end{array}$ & 38 & 45 & $84 \%$ \\
\hline 8. & $\begin{array}{l}\text { Audio appeal (music, } \\
\text { sound effects, or narration) } \\
\text { in an educational game }\end{array}$ & $\begin{array}{c}5445444 \\
44\end{array}$ & 39 & 45 & $86 \%$ \\
\hline 9. & $\begin{array}{l}\text { Display text and writing } \\
\text { (font) in educational games }\end{array}$ & $\begin{array}{c}4444333 \\
43 \\
\end{array}$ & 32 & 45 & $70 \%$ \\
\hline 10. & $\begin{array}{l}\text { Combination, order and } \\
\text { color selection in } \\
\text { educational games }\end{array}$ & $\begin{array}{c}4544444 \\
44\end{array}$ & 37 & 45 & $82 \%$ \\
\hline \multicolumn{5}{|c|}{ Overall percentage average } & $81 \%$ \\
\hline
\end{tabular}

Table 4. Components Assessed in Large Group (Field) Trial

\begin{tabular}{|c|c|c|c|c|c|}
\hline No. & Components assessed & $\begin{array}{l}\text { A score of } 21 \\
\text { respondents }\end{array}$ & $\begin{array}{l}\text { Total } \\
\left(\sum\right) \\
\text { score }\end{array}$ & $\begin{array}{l}\text { Total }\left(\sum\right) \\
\text { maximum } \\
\text { score }\end{array}$ & $\begin{array}{l}\text { Percentage } \\
(\%)\end{array}$ \\
\hline 1. & $\begin{array}{l}\text { The ability of educational } \\
\text { games is able to convey the } \\
\text { subject matter of letters } \\
\text { and basic words }\end{array}$ & $\begin{array}{lllllll}4 & 5 & 5 & 5 & 4 & 5 & 4 \\
4 & 5 & 4 & 5 & 4 & 3 & 4 \\
3 & 54 & 4 & 545\end{array}$ & 90 & 105 & $86 \%$ \\
\hline 2. & $\begin{array}{l}\text { Clarity of contents in the } \\
\text { educational game. }\end{array}$ & $\begin{array}{lllllll}4 & 4 & 4 & 4 & 4 & 4 & 3 \\
5 & 4 & 3 & 4 & 4 & 4 & 4 \\
4 & 4 & 5 & 4 & 4 & 5 & 4\end{array}$ & 85 & 105 & $81 \%$ \\
\hline 3. & $\begin{array}{l}\text { Animated clarity in } \\
\text { educational games. }\end{array}$ & 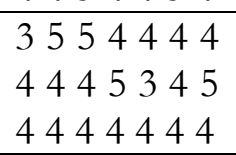 & 86 & 105 & $82 \%$ \\
\hline 4. & $\begin{array}{l}\text { Text and voice clarity in } \\
\text { the educational game. }\end{array}$ & $\begin{array}{lllllll}4 & 454554 \\
4 & 44433 & 5 \\
3444 & 4544\end{array}$ & 87 & 105 & $83 \%$ \\
\hline 5. & $\begin{array}{l}\text { The ability of educational } \\
\text { games to facilitate learning. }\end{array}$ & $\begin{array}{l}44533444 \\
4445444 \\
4454443\end{array}$ & 85 & 105 & $81 \%$ \\
\hline 6. & $\begin{array}{l}\text { Ease when operating or } \\
\text { running an educational } \\
\text { game. }\end{array}$ & $\begin{array}{l}4544444 \\
4444444 \\
5544544\end{array}$ & 88 & 105 & $84 \%$ \\
\hline 7. & $\begin{array}{l}\text { Visual appearance (picture, } \\
\text { video, or animation) in } \\
\text { facilitating learning }\end{array}$ & $\begin{array}{lllllll}3 & 4 & 4 & 4 & 5 & 4 & 3 \\
5 & 5 & 3 & 4 & 5 & 5 & 4 \\
4 & 4 & 4 & 5 & 3 & 4 & 4\end{array}$ & 86 & 105 & $82 \%$ \\
\hline 8. & $\begin{array}{l}\text { Audio appeal (music, } \\
\text { sound effects, or narration) }\end{array}$ & $\begin{array}{l}4453454 \\
5444445 \\
\end{array}$ & 85 & 105 & $81 \%$ \\
\hline
\end{tabular}

103 | ISLLAC : Journal of Intensive Studies on Language, Literature, Art, and Culture 


\begin{tabular}{|c|c|c|c|c|c|}
\hline & in an educational game & 4443443 & & & \\
\hline 9. & $\begin{array}{l}\text { Display text and writing } \\
\text { (font) in educational games }\end{array}$ & $\begin{array}{l}4544444 \\
4434554 \\
5554344\end{array}$ & 88 & 105 & $84 \%$ \\
\hline 10. & $\begin{array}{l}\text { Combination, order and } \\
\text { color selection in } \\
\text { educational games }\end{array}$ & $\begin{array}{lllllll}3 & 4 & 4 & 3 & 4 & 5 & 4 \\
5 & 5 & 4 & 4 & 4 & 4 & 4 \\
4 & 4 & 4 & 5 & 4 & 3 & 4\end{array}$ & 85 & 105 & $81 \%$ \\
\hline \multicolumn{5}{|c|}{ Overall percentage average } & $82 \%$ \\
\hline
\end{tabular}

\section{Discussions}

From the data generated during individual trials consisting of three School Of Liberal Arts students, it is known that the overall percentage average of the quality of educational games is $78 \%$. This shows that educational game products "Halo Indonesia" are in "high" qualifications and do not require revisions. From the data generated during a small group trial consisting of nine School Of Liberal Arts students, it was found that the overall percentage average of the quality of educational games was $81 \%$. This shows that educational game products "Halo Indonesia" are in "high" qualifications and do not require revisions. From the data generated during a large group trial or field consisting of twenty-four School Of Liberal Arts students, it is known that the overall percentage average of the quality of educational games is $82 \%$. This shows that educational game products "Halo Indonesia" are in "high" qualifications and do not require revisions.

The feasibility test that produces high criteria indicates that the educational game "Halo Indonesia" can be accepted by Thai citizens, especially by Walailak University students. This can not be separated from the appearance of an interesting game, clear sound, easy operation of the game, easy to read the writing, in accordance with the content being taught, and can be played anywhere using an Android smartphone. An explanation of the educational game "Halo Indonesia" is presented in the following table:

Table 5. Some Screenshot of Educational Games "Halo Indonesia"

\begin{tabular}{|c|c|c|}
\hline No. & Screenshot of Educational Game & Description \\
\hline 1. & & $\begin{array}{l}\text { - The start page of the educational game } \\
\text { "Halo Indonesia". } \\
\text { - Showing Indonesian cultures that appear } \\
\text { in the background and characters in the } \\
\text { game. } \\
\text { - Using traditional Indonesian music } \\
\text { backsound. }\end{array}$ \\
\hline 2. & (Q.) & $\begin{array}{l}\text { - Biodata page for educational game } \\
\text { developers "Halo Indonesia". } \\
\text { - Collaboration between two universities, } \\
\text { namely Trunojoyo Madura University } \\
\text { and Walailak University. }\end{array}$ \\
\hline 3. & 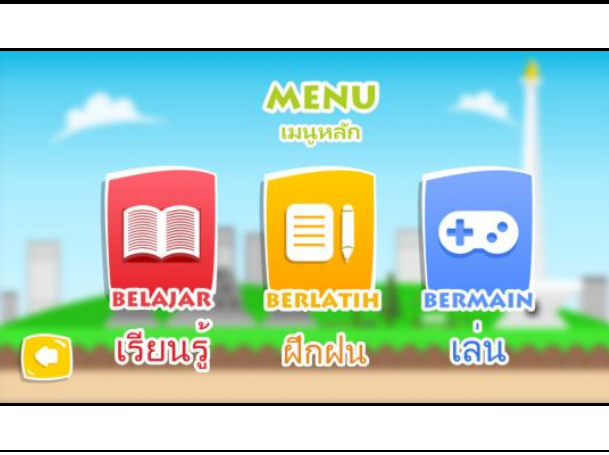 & $\begin{array}{l}\text { - The "Menu" page that displays three } \\
\text { choices. } \\
\text { - "Learning" options to know things about } \\
\text { Indonesia. } \\
\text { - The choice of "Practice" to practice } \\
\text { pronouncing letters and words and } \\
\text { writing basic words in Indonesian. } \\
\text { - Option "Play" to play guessing games } \\
\text { related to the basic Indonesian words. }\end{array}$ \\
\hline
\end{tabular}

104 | ISLLAC : Journal of Intensive Studies on Language, Literature, Art, and Culture 


\begin{tabular}{|c|c|c|}
\hline 4. & (II) PELLANARAN บทเ (Iียน & $\begin{array}{l}\text { - In the "Learning" menu there are eleven } \\
\text { sub-menu choices. } \\
\text { - Eleven sub-menus contain matters } \\
\text { relating to Indonesia, such as maps, } \\
\text { government, national anthem, currency, } \\
\text { famous tourist sites, and so on. } \\
\text { - Explanation in this menu uses Thai. }\end{array}$ \\
\hline 5. & BELAURR If & $\begin{array}{l}\text { - Sample display in the "Indonesian } \\
\text { Tourism" submenu. } \\
\text { - Available images and tourist locations } \\
\text { can be raised online through google } \\
\text { maps in educational games. }\end{array}$ \\
\hline 6. & BELAUAR & $\begin{array}{l}\text { - Display in the "National Anthem" } \\
\text { submenu. } \\
\text { - Display video clips of Indonesia Raya } \\
\text { songs accompanied by Indonesian and } \\
\text { Thai languages. }\end{array}$ \\
\hline 7. & 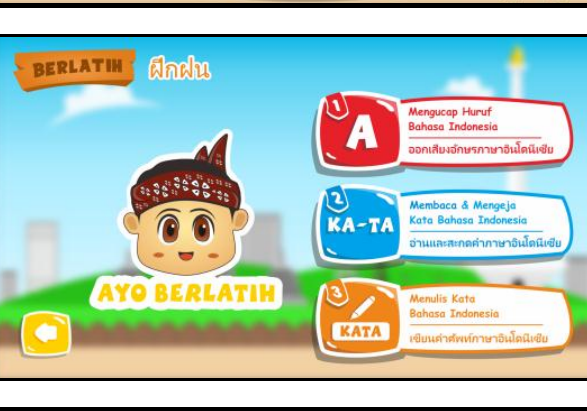 & $\begin{array}{l}\text { - On the "Practice" menu there are three } \\
\text { submenus. } \\
\text { - The first submenu is to say Indonesian } \\
\text { letters. } \\
\text { - The second submenu is reading and } \\
\text { spelling. } \\
\text { - The third submenu is writing the } \\
\text { Indonesian word. }\end{array}$ \\
\hline 8. & 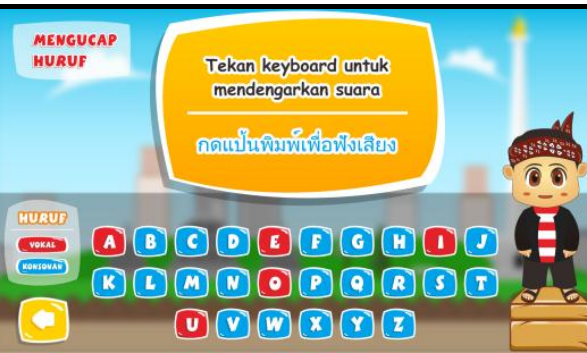 & $\begin{array}{l}\text { - The display in the submenu "says } \\
\text { letters". } \\
\text { - The user presses one of the letters and } \\
\text { the voice and writing will appear in Thai. }\end{array}$ \\
\hline 9. & 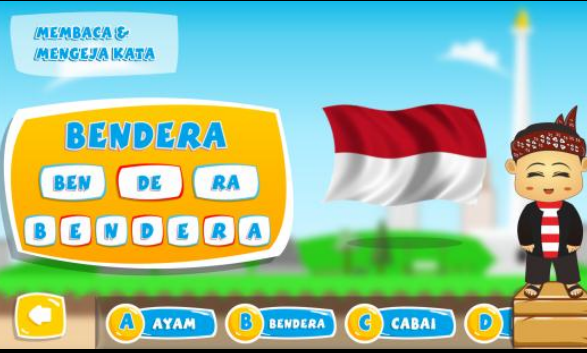 & $\begin{array}{l}\text { - The display in the submenu "reads and } \\
\text { spells words". } \\
\text { - The user presses one of the word } \\
\text { choices, then a way to spell and read the } \\
\text { word will appear. } \\
\text { - How to spell and read words appear in } \\
\text { the form of sounds and writing. }\end{array}$ \\
\hline 10. & 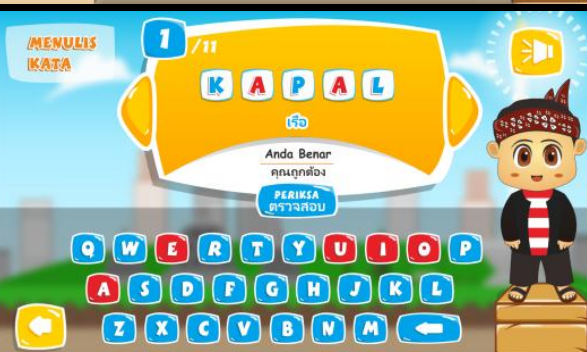 & $\begin{array}{l}\text { - The display in the submenu "writes } \\
\text { words". } \\
\text { - The user presses the speaker symbol and } \\
\text { a sound will be heard. } \\
\text { - Users are asked to arrange words based } \\
\text { on the sound that appears. }\end{array}$ \\
\hline
\end{tabular}

105 | ISLLAC : Journal of Intensive Studies on Language, Literature, Art, and Culture 


\begin{tabular}{|c|c|c|}
\hline 11. & 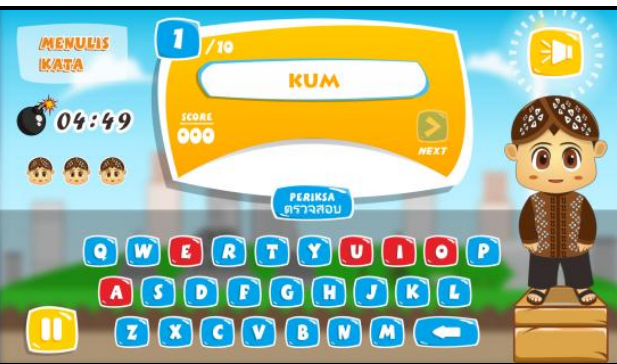 & $\begin{array}{l}\text { - In the "Play" menu, users will play games } \\
\text { related to Indonesian. } \\
\text { - Instructions for playing will be presented } \\
\text { before the game starts. } \\
\text { - Users are given the opportunity to only } \\
\text { make three mistakes. }\end{array}$ \\
\hline
\end{tabular}

\section{CONCLUSIONS AND SUGGESTIONS}

From the results of the development research that has been carried out, it can be concluded that the educational game "Halo Indonesia" has been declared feasible in the test of the level of effectiveness, efficiency, and attractiveness. This educational game presents games related to Indonesian, especially letters and basic words. The advantage of this game is in the sound that appears to mention letters or words in Indonesian. From that sound, the user can find out how to read and spell correctly then learn to imitate the sound.

Additional instruments in the educational game, such as images, animations, music and sound effects optimally can attract users to linger playing this educational game. Besides being entertained, users will also be invited to learn Indonesian when playing this educational game. Although this educational game has entertainment value, it still focuses on the learning objectives, which is to teach users to pronounce letters and words in Indonesian.

Suggestions for the use of products from the development of educational games "Halo Indonesia" are as follows:

a. Use the handset or earphone to more clearly hear the sounds that appear in this educational game.

b. Combine this educational game with other learning strategies or methods to make it more challenging, the teacher can create competitions and prizes for the winner or winner of the highest game value.

c. For further development, this educational game should also be developed on the IoS platform.

\section{REFERENCES}

Ariona, Rima. (2014). Game Edukasi Pengenalan Warna Sebagai Media Pembelajaran Anak Usia Prasekolah Berbasis Android. Jurnal Teknik Elektro Unnes: Vol. 3 No. 2 (Juli - Desember 2014).

Aprilina, Cheri dan Al Fatta, Hanif. (2014). Perancangan Game Edukasi "Cooking for Child". Jurnal DASI Amikom Yogyakarta: Vol. 9 No. 4 (Desember 2014).

Kompasiana. (2017). Tren Anak Muda Thailand Belajar Bahasa Indonesia. Diakses4November2018.https://www.kompasiana.com/genturtama/58e6650ae7afbd720ec119d9/t ren-anak-muda-thailand-belajar-bahasa-indonesia

Ramansyah, Wanda. (2010). Pengembangan Multimedia Pembelajaran Interaktif Berbasis Komputer Pada Mata Diklat Dasar-Dasar Mesin. Tesis tidak diterbitkan. PPS Universitas Negeri Malang.

Sadiman, Arief, S. (2008). Media Pendidikan: Pengertian, Pengembangan, dan Pemanfaatannya. Jakarta: PT. Raja Grafindo Persada.

Sink, Darryl L. (2014). Design Models and Learning Theories for Adults. American Society for Training and Development.

Smaldino, Sharon E. (2011). Instructional Technology and Media for Learning. New Jersey: Pearson Education Ltd.

Tribun News. (2017). Bahasa Indonesia Jadi Tren Di Thailand, Kenapa Yah?. Diakses 4 November 2018. http://www.tribunnews.com/nasional/2017/10/26/bahasa-indonesia-jadi-tren-di-thailand-kenapa-yah 